\title{
ON THE HYDROID MERONA CORNUCOPIAE (NORMAN)
}

\author{
By W. J. Rees \\ (Text-figs. I-3)

\section{INTRODUCTION}

British Museum (Natural History), London

During a short visit of seven days to the Station Biologique, Roscoff, in June I955, I was able to make some observations on living colonies of Merona cornucopiae (Norman) and on other hydroids. The object of my visit was to see living polyps of Tricyclusa singularis which were also found, but unexpectedly Merona was found during dredging and provided the opportunity for a much needed re-description from living material.

I am grateful to Professor Georges Teissier for kindly placing a table at my disposal at Roscoff, and also to Dr Claude Levi and Dr Bertil Swedmark for many kindnesses during my stay.

\section{A RE-DESCRIPTION OF MERONA CORNUCOPIAE (NORMAN)}

There has been no adequate description of Merona cornucopiae since Norman (I864) described the species from preserved material from the Shetlands, although Garstang (1892) described some features of a large colony from Plymouth.

\section{Material}

Colonies found on Glycimeris glycimeris (L.) (Fig. I) and Turritella communis Lamarck, dredged from I5 to $25 \mathrm{~m}$ off Callot in the Baie de Morlaix on 23 June I955, were examined alive, and the following description is based mainly on this material, supplemented by a re-examination of preserved material in the British Museum (Natural History).

The Museum material examined is noted below.

\section{Shetland}

On Dentalium entale inhabited by Phascolion, fertile. B.M. No. I9I2.12.2I.255. Coll. A. M. Norman (Syntype). This colony is in alcohol; the hydranths have partially disappeared but the perisarcal tubes and the reproductive polyps with their mulberrylike bunches of gonophores remain.

On two shells of Dentalium entale with Phascolion, sterile, I867. B.M. No. 1912.12.21.254. Coll. A. M. Norman. There are no polyps and the perisarcal tubes are well covered with adhering sand grains. This colony was probably dead when collected. 


\section{Plymouth}

On Aporrhais pes-pelecani inhabited by Phascolion strombi, sterile. B.M. No. I9IO. IO.I. I. Coll. A. M. Norman. The hydranths are well retracted into the perisarcal tubes which have a height of $3.0-4.0 \mathrm{~mm}$. The tubes have a diameter of about $0.14 \mathrm{~mm}$ at the base and expand gradually distally and have a diameter of about $0.35 \mathrm{~mm}$ at the rim.

On two living Dentalium entale, sterile, Eddystone Grounds, 26 May I898, B.M. No. I948.9.8.53. Coll. E. T. Browne. No hydranths or gonophores are present. The taller perisarcal tubes have lengths of $1 \cdot 98-3.34 \mathrm{~mm}$. The stolons have diameters of $0.06-0.08 \mathrm{~mm}$.

On one living D. entale, fertile, Eddystone Grounds, 4 June I898, B.M. No. I94I . 3 20.5 I6. Coll. E. T. Browne. This colony occurs right at the tip of the Dentalium shell. The polyps have been killed in an expanded condition and are very life-like. The reproductive polyps have long stalks like the nutritive ones and are further discussed on p. 502. Measurements of this colony are given in Table I.

On a dead Aporrhais pes-pelecani, sterile; off Stoke Point, 4 November I9r3. B.M. No. 1948.9.8. I8. Coll. E. T. Browne. Sterile colony with short stems and polyps moderately extended.

Fragments from the shell of Glycimeris glycimeris (L.), sterile, I8 March I9I4. B.M. No. 1948. I0.1.26. Coll. E. T. Browne. Fragments with few polyps; stems I.0-3.5 mm high.

Three colonies each on Dentalium entale, fertile. B.M. No. I921.8.31.5 (purchased). Colonies on the apices of the shells; each colony with tall reproductive polyps of the same length as the nutritive polyps.

Eastern Channel, position, $50^{\circ} 28^{\prime} 45^{\prime \prime} \mathrm{N} ., 00^{\circ} \circ 5^{\prime} \mathrm{W}$.

On Glycimeris glycimeris (L.), sterile, 49 m., 24 July I947. Manihine Collections. A small sterile colony with retracted polyps.

\section{Description}

All the colonies seen by me have consisted of Io-40 nutritive polyps, with or without a small number of reproductive polyps, but Garstang (I892) noted a very large colony of 90-I00 polyps covering almost the whole upper surface of a shell of Aporrhais pes-pelecani inhabited by the sipunculid Phascolion strombi. In this colony the hydrorhiza formed a continuous crust, whereas in Norman's colonies and others in the Museum, the stolons sometimes form a crust and sometimes a reticulate network. When the stolons can easily be seen (as on Dentalium), they are seen to be covered with smooth, non-annulated, horn-coloured perisarc; they have diameters of $0.06-0.08 \mathrm{~mm}$.

The unbranched polyp stems have a height (to hypostome) of $2.0-5.0 \mathrm{~mm}$ when the polyp is expanded. The stems are not usually vertical but slope in the direction of the ciliary currents of the host mollusc; they arise directly from the hydrorhiza with a diameter at base of about 0.I4 $\mathrm{mm}$. They expand gradually distally to a diameter of $0.4-0.56 \mathrm{~mm}$. The distal margin is often flared into a trumpet-shape but this feature is more noticeable in young polyps than in old ones which become coated with sand grains or fine mud. When the 
polyps die down and regenerate, new tubes arise within the mouths of the old ones as noted by Norman, but this feature is not always apparent and caused Garstang to remark: 'The lines of growth encircling the hydrothecae nowhere project so as to assume a ridge-like form, as shown in Norman's figure.'

The large polyps have a length of up to $5 \mathrm{~mm}$ when expanded, and have about twenty long filiform tentacles scattered over the anterior half (Figs. I, 2). Tentacles proximal to the mouth seem to be arranged in an oral whorl of four to seven in number. The proboscis is bluntly rounded and of an intense white

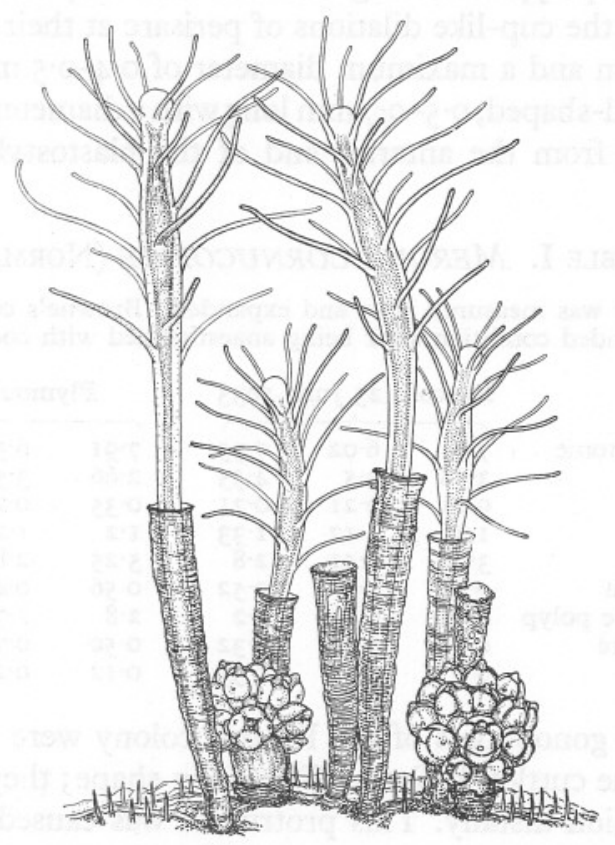

Fig. I. Merona cornucopiae (Norman): a portion of a fertile colony dredged off Callot, Baie de Morlaix, 23 June 1955; drawn from life.

colour but posterior to it the digestive endoderm is orange brown to scarlet in colour, and this fades distally to an uniformly pale tint in the non-tentacular portion of the polyp. When brought in from the dredgings the polyps were contracted into their perisarcal tubes with only the tip of the hypostome and the tips of the oral tentacles visible. They did not expand into full length until nearly I 2 hours had passed. In the Roscoff colonies the perisarc is of a pale horn colour and rather opaque; it was usually covered with a fine layer of mud particles. The dimensions of the Roscoff and Plymouth colonies are given in Table I.

The gonophores in one of the Roscoff colonies were, as Norman stated, borne in the form of mulberry-like masses on very short stalks arising from 
openings in the stolons. These reproductive polyps have short collars of perisarc at their point of origin on the stolons. It was noticed by Garstang (I892) that 'the blastostyles invariably possess a slender terminal portion, with a slightly dilated apex, which is prolonged beyond the mulberry-like mass of gonophores except when contracted. It is an interesting vestigial structure being homologous with the tentacular portion of a digestive polyp....'

In one of E. T. Browne's well-preserved colonies (B.M. No. I94I ·3 20.5I6) these reproductive polyps had long stalks so that they had a total height of $\mathrm{I} \cdot 75-3.5 \mathrm{~mm}$, but the cup-like dilations of perisarc at their base had a height of only $0.4-0.6 \mathrm{~mm}$ and a maximum diameter of $0.4-0.5 \mathrm{~mm}$ (Fig. 2). Each gonophore was pod-shaped, $0.5-0.7 \mathrm{~mm}$ long with a diameter of $0.12-0.22 \mathrm{~mm}$. They arise single from the anterior end of the blastostyle and not in any particular order.

\section{TABle I. MERONA CORNUCOPIAE (NORMAN)}

The Roscoff colony was measured alive and expanded. Browne's colony from Plymouth was killed in an expanded condition after being anaesthetized with cocaine. Measurements in $\mathrm{mm}$.

Total height to hypostome

Length of polyp

Diameter of polyp

Length of tentacle

Height of stem

Max. diameter of stem

Height of reproductive polyp

Diameter of gonophore

Length of gonophore

$\begin{array}{lll}7.0 & 6.02 & 7.35 \\ 3.78 & 3.5 & 4.55 \\ 0.21 & 0.21 & 0.21 \\ I .36 & \text { I.12 } & \text { I.33 } \\ 3.22 & 2.52 & 2.8 \\ 0.56 & 0.5 & 0.52 \\ 0.84 & 0.84 & 1.2 \\ 0.24 & 0.28 & 0.32 \\ 0.4 & 0.32 & 0.35\end{array}$

Plymouth, 4 June I898

$\begin{array}{llll}7.91 & 6.3 & 9.59 & 7.28 \\ 2.66 & 3.5 & 5.04 & 3.08 \\ 0.35 & 0.28 & 0.28 & 0.28 \\ \mathrm{I} \cdot 2 & 1.25 & 1.3 & \mathrm{I} \cdot 1 \\ 5.25 & 2.8 & 4.55 & 4.2 \\ 0.56 & 0.49 & 0.56 & 0.42 \\ 2.8 & 1.75 & 3.5 & - \\ 0.50 & 0.7 & 0.6 & 0.6 \\ 0.12 & 0.22 & 0.22 & 0.2\end{array}$

By contrast the gonophores of the Roscoff colony were styloid and rather like the eggs of the cuttlefish Sepia officinalis in shape; they were round with a teat-like protrusion distally. This protrusion was caused by the tip of the scarlet-coloured spadix. The eggs were pinkish in colour and few in number (two to six). Male gonophores were not seen by me.

\section{Distribution}

Although Merona cornucopiae is probably not a rare species in our waters, records of its occurrence are few, but these indicate that it may be found all round our coasts except perhaps in the southern North Sea. The species is known from the following localities: Shetland (Norman, I864), Northumberland (Alder, I867), 2 miles north-east of Bamborough Castle (Schulze, I875), the Plymouth area (Garstang, I892, I894; Allen, I899; Crawshay, I9I2), the Isle of Man (Moore, I933, I937), Blacksod Bay, Ireland (Duerden, I895) and the Eastern Channel (this paper, p. 500).

Outside British waters the hydroid has been taken at Roscoff (Teissier, I950), the Faroes (Broch, I9I6), the Eastern Kattegat (Kramp, I935) and in the 
Mediterranean (Graeffe, I884; Motz-Kossowska, 1905). On the North American coast it has been recorded from New England by Verrill (I879) and by Fraser (1936) from Queen Charlotte Islands, British Columbia.

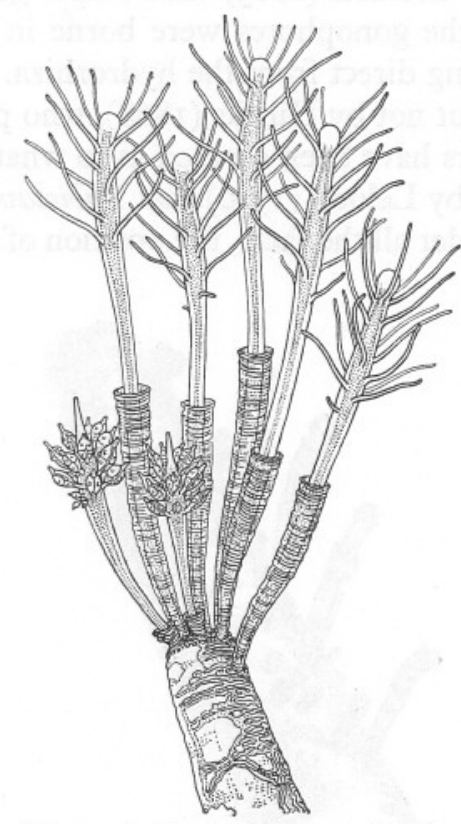

Fig. 2. Merona cornucopiae (Norman): fertile colony at the tip of a shell of Dentalium entale, Eddystone Grounds, Plymouth, 4 June I898; E. T. Browne Collection (Brit. Mus. No. I94I.3.20.5I6). This colony was anaesthetized with cocaine.

\section{Biology}

Merona cornucopiae exhibits a preference for the shells of molluscs as a substratum. Where the mollusc is a bivalve like Glycimeris glycimeris, the colonies are found at the posterior or postero-ventral margin of the valves, and the stems always lean towards this edge, so that the polyps when expanded project into the ciliary feeding currents of the host. Similarly, the colonies on Dentalium are found strategically placed close to the tip of the shell.

In British waters Merona has been found on D. entale L., Astarte sulcata (da Costa), Glycimeris glycimeris (L.) and Venus fasciata (da Costa), but it has also been found on dead gastropod shells of Aporrhais, Turritella and Natica inhabited by the sipunculid Phascolion strombi. Farther afield it has been reported on Cardium from the Faroes by Broch (I9I6) and on an old skeleton of a gorgonian at Banyuls by Motz-Kossowska (1905).

Fertile colonies of Merona have been taken at Plymouth in May and June. The species has a bathymetric range of IO-I $82 \mathrm{~m}$ in British waters, but it has been recorded from a depth of $274 \mathrm{~m}$ in the Faroes (Broch, 1916). 


\section{Discussion}

When Norman first described his species cornucopiae he placed it in Tubiclava Allman I863, but later decided (I865) that a new genus, Merona, must be created for it, because the gonophores were borne in clusters at the tips of short gonoblastidia arising direct from the hydrorhiza. Merona was accepted by Allman (I87I-72), but not by Hincks (I868), who preferred to retain it in Tubiclava. Later authors have been divided as to what genus to use, and the conclusion was reached by Leloup (I930) that Tubiclava should be employed. As Leloup did not consider all the facts, the position of the species cornucopiae is discussed below.

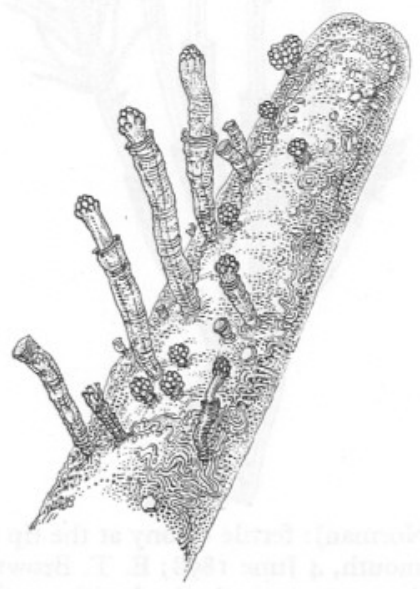

Fig. 3. Merona cornucopiae (Norman): a sketch of one of Canon Norman's type colonies on Dentalium entale from the Shetlands (Brit. Mus. No. I9I2.12.21.255).

The re-description of $M$. cornucopiae shows that the reproductive polyps are sometimes tall and may resemble nutritive polyps in which the tentacles had been resorbed through reproductive exhaustion (comparable to what takes place in species of Hydractinia, Coryne and Zanclea). If this were so, it would narrow the distinction between Merona and the more typical Clava-like hydroids, but there is no evidence that the reproductive polyp ever possesses tentacles, and it is very significant that the Merona reproductive polyp never possesses more than a short collar of perisarc at the base. This last feature indicates that Merona possesses two distinct types of polyp and that the reproductive ones are not derived by reduction from the long-stemmed nutritive ones.

Leloup pointed out that Merona was distinguished from Tubiclava only by '(a) les gonophores prennant naissance sur des polypes reduits au blastostyle; (b) le perisarque lisse des ses hydranthes et assez large à sa partie pour reçevoir l'hydranthe retracté'. Evidence has already been presented which 
indicates that the reproductive polyps of Merona are special ones, not derived from the ordinary nutritive ones. Leloup based his case on the fact that the hydranths of a Mediterranean species, Tubiclava pusilla Motz-Kossowska, became reduced to blastostyles, so narrowing (in his opinion) the gap between the two genera.

Leloup, however, did not consider the status of T. lucerna Allman I863; this, the type species, is a problematic one whose identity is uncertain, for Allman himself later doubted whether he had actually observed fixed gonophores in this species (Allman, I872, p. 256). T. lucerna has a closely adherent perisarc below the hydranth, so that the latter is not retractile as in Merona, and more properly belongs to the group of hydroids which have at various times been referred to Corydendrium, Dendroclava and Turritopsis. Allman's second species Tubiclava fruticosa, described without knowledge of its gonophores, also belongs to this group (of which only Turritopsis nutricola McCrady is known from British waters from its medusa only). I propose to regard Tubiclava as a possible synonym of Turritopsis, but it should be noted that Tubiclava pusilla, on which Leloup based his arguments, does not appear to belong to the Turritopsis group, and its status will have to be clarified when it is found again.

Merona Norman may therefore be confidently accepted as a well-constituted genus for Tubiclava cornucopiae.

\section{SUMMARY}

Merona cornucopiae (Norman) is re-described from living material from the Baie de Morlaix, supplemented by a re-examination of material in the British Museum (Nat. Hist.). Merona Norman is demonstrated to be a valid genus while Tubiclava Allman (in which $M$. cornucopiae is placed by some authors) is shown to have affinities with the Turritopsis-Corydendrium group of clavid hydroids.

\section{REFERENCES}

ALDER, J. I867. Reports of deep-sea dredging on the coasts of Northumberland and Durham, I862-I864. Report on the Zoophytes. Trans. nat. Hist. Northumb. Durh., Vol. I, pp. I-58.

Allen, E. J., I899. On the fauna and bottom deposits near the thirty fathom line from the Eddystone Grounds to Start Point. F. mar. biol. Ass. U.K., Vol. 5, pp. $365-542$.

Allman, G. J., I871-72. A Monograph of the Gymnoblastic or Tubularian Hydroids. $450 \mathrm{pp}$. London: Ray Soc.

BRoch, Hj., I9r6. Hydroida (Part I). Dan. Ingolf-Exped., Vol. 5, Pt. 6, pp. I-66.

CraWSHAY, L. R., I9I2. On the fauna of the outer western area of the English Channel. F. mar. biol. Ass. U.K., Vol. 9, pp. 292-393.

DUERDEN, J. E., I895. Survey of the fishing grounds, west coast of Ireland, I890-9I. Notes on the Hydroida and Polyzoa. Sci. Proc. R. Dublin Soc., N.S., Vol. 8, pp. $325-36$. 
Fraser, C. M., I936. Hydroids from the Queen Charlotte Islands. F. biol. Bd Canada, Vol. I, pp. 503-7.

GARSTANG, W., I892. On some new or rare marine animals recently discovered on the coast of Devonshire. Trans. Devon. Ass. Adv. Sci., Vol. 24, pp. 377-86.

- I894. Faunistic notes at Plymouth during I893-I894; with observations on breeding seasons of marine animals, and on periodic changes of the floating fauna. F. mar. biol. Ass. U.K., Vol. 3, pp. 210-35.

GRAEFFE, E., I884. Uebersicht der Seethierfauna des Golfes von Trieste nebst Notizen über Vorkommen, Lebensweise, Erscheinungs-und Fortpflanzungszeit der einzelnen Arten III. Coelenteraten. Arb. zool. Inst. Univ. Wien, Bd. 5, pp. $333-62$.

Hincks, T., I868. A History of British Hydroid Zoophytes, 2 Vols. 328 pp. London: van Voorst.

Kramp, P. L., I935. Polypdyr (Coelenterata), I. Ferskvandspolypper og Goplepolypper. Danmarks Fauna, Vol. 4I, pp. I-208.

Leloup, E., 1930. A propos de Tubiclava pusilla Motz-Kossowska et du genre Merona Norman. Ann. Soc. zool. Belg., T. 60, pp. 24-8.

Moore, H. B., I933. New faunistic records for the Manx region. Rep. mar. Biol. Sta. Pt Erin, Vol. 46, pp. 30-4.

- 1937. Marine Fauna of the Isle of Man. Proc. Lpool biol. Soc., Vol. 50, pp. I-293.

MotZ-Kossowska, S., 1905. Contribution à la connaissance des Hydraires de la Mediterranée occidentale. I. Hydraires gymnoblastiques. Arch. Zool. exp. gén., Sér. 4, T. 3, pp. 39-98.

Norman, A. M., I864. On undescribed British Hydrozoa, Actinozoa and Polyzoa. Ann. Mag. nat. Hist., Ser. 3, Vol. 13, pp. 82-90.

- 1865. On Merona, an undescribed genus of British Hydrozoa. Ann. Mag. nat. Hist., Ser. 3, Vol. 15, pp. 26I-2.

Schulze, F. E., I875. Coelenteraten. Fber. Comm. dtsch. Meere Kiel, Jahrg. 2-3, (I872-73), pp. I2I-I 42 , pl. ii.

Teissier, G., I950. Inventaire de la faune marine de Roscoff: Cnidaires et Cténaires. Trav. Sta. biol. Roscoff, 1950, Suppl. I, pp. I-43.

VerRILL, A. E., I879. Preliminary check list of the marine Invertebrata of the Atlantic from Cape Cod to the Gulf of St Lawrence. Prepared for the United States Commission of Fish and Fisheries. 